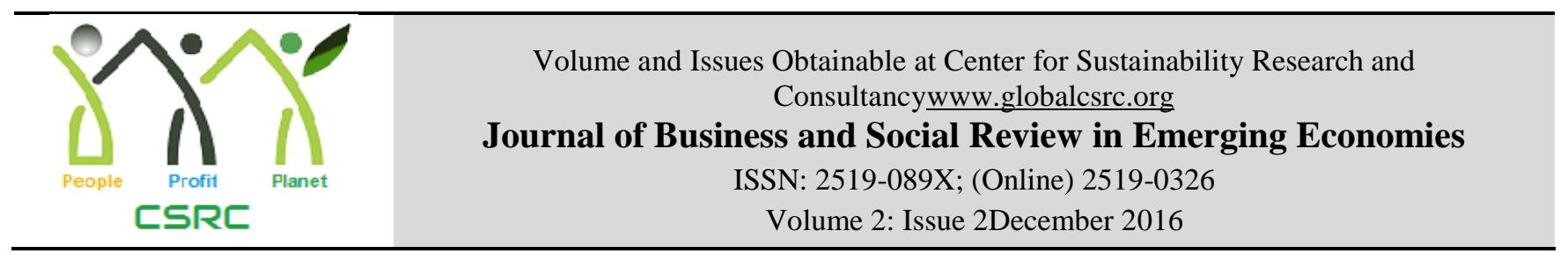

\title{
The Effects of Artificial Reefs to Fishermen Income
}

\author{
${ }^{1}$ Haspinor bintiTeh, ${ }^{2}$ Jamal bin Ali, ${ }^{3} \mathrm{~K}$. Kuperan Viswanathan \\ ${ }^{1,2}$ School of Economics, Finance and Banking, College of Business, Universiti Utara Malaysia, 06010, Sintok, \\ Kedah, Malaysia. Email: pnot 86@yahoo.com.sg, jamalali@uum.edu.my \\ ${ }^{3}$ Othaman Yeop Abdullah (OYA), Graduate School of Business, Universiti Utara Malaysia, 06010, Sintok, \\ Kedah, Malaysia. Email: kuperan@uum.edu.my
}

\begin{tabular}{l}
\hline ARTICLEDETAILS \\
\hline History \\
Revised format: Nov 2016 \\
AvailableOnline: Dec 2016
\end{tabular}

\begin{tabular}{l}
\hline Keywords \\
Artificial reef, \\
Kedah, \\
Traditional fisherman, \\
fisherman income
\end{tabular}

JEL Classification: H24,H29

\begin{abstract}
Purpose: This paper will examine the effects of artificial reefs on the income of fishermen in Kuala Kedah and Pulau Langkawi, Kedah.

Design/methodology/approach: The method used was based on interviews with fishermen in Kuala Kedah and Pulau Langkawi in Kedah. Interview questions were prepared and carried out pilot tests in advance to see the appropriateness of the questions. The data obtained were analyzed using the Statistical Package for the Social Sciences (SPSS).

Findings: From the results of the study clearly shows that artificial reefs affects the income of fishermen. Artificial reefs not only increase the income, but the area also give the benefit to the tourist and divers.

Research limitations/implications: This study involved the fisherman in Pulau Langkawi and Kuala Kedah, Kedah. Data wass collected randomly in two areas of this fishing village with total of 240 traditional fishermen.

Practical implications: Implementation of artificial reefs to increase the income of fishermen and one of the ways to solve the problem of fisheries resources in the long term.

Originality/value: The effectiveness of artificial reefs to the income of fishermen and others factor that influence the income of fishermen.
\end{abstract}

(C) 2016 The authors, under a Creative Commons Attribution-

NonCommercial 4.0

\section{Introduction}

A person's happiness when he is with his family depends on a number of internal and external factors. An internal The fisheries sector in Malaysia contributed around 1.1 percent of the Gross Domestic Product (GDP) in 2014 (Department of Fisheries Malaysia (DOFM), 2015). While the contribution of the fisheries sector to GDP seen small, but the importance of the fisheries sector as a major supplier of protein sources (Tey, Shamsudin, Mohamed, Abdullah and Radam, 2008) and a main sectors of

*Corresponding author's email address: pnot_86@yahoo.com.sg

Recommended citation: Teh, B. H., Ali, B. J., Viswanathan, K. K.(2016). The Effects of Artificial Reefs to Fishermen Income.Journal of Business and Social Review in Emerging Economies,2(2)117-126. DOI:

https://doi.org/10.26710/jbsee.v2i2.28 
employment for those living in coastal areas. Consumption per capita of fish as the main protein source in Malaysia is $45.5 \mathrm{~kg}$ per year, compared with meat just around $5.6 \mathrm{~kg}$ per year (Department of Statistics, 2014). This effected by the factor price of fish that more cheaper than meat price. This situation make demand of fish increase from $33.4 \mathrm{~kg}$ per year in 1986 to $45.5 \mathrm{~kg}$ per year in 2012 . To fulfill high demand in this sector, overfishing was happened. Besidethats, country had to import from other countries like Thailand to fulfill fish demand in Malaysia.

The high demand for fish has caused over exploitation. This situation make a fisheries resources decrease and in long term marine resouces will collapes. The decline in fisheries resources has become a huge issue that will be an effect to traditional fishermen and country. This is because over $60 \%$ of the main source of supply of fish comes from coastal fishing (Malaysian Fisheries Development Authority (MFDA), 2014; Maznah, 2013).

In 2012 the number of fishing landings are 1.4 million tonnes with a value of RM 7857.85 million. This number isexpected to increase in 2020 with an increase of 1.8 million with an increase of 2.9 per cent per annum. However, if the resource continues decline, it will affect the national target for the fishery products landed by 500 thousand tonnes in 2020 (Ariff, Sharir, Ali, Majid and Hussin, 2011). Because of this situation, country has introduced artificial reef for long term solutions.

Artificial reefs are manmade that has a potential to accumulate and increase the production of fish (Ali, 2007; Shahbudin, Hafifi, Akbar, Kamaruzzaman, and Jalal, 2011; Ali, Hussain, Hamid and Abdullah, 2013). The implementation of the concept of artificial reefs is to put something natural or man-made material on the seabed for the purpose of replenishing the local fishery resources. After a period, these reefs will change to a suitable habitat for protection, construction and where to find food to most of the species and habitats of various flora and fauna (Ali, 2007).

Artificial reefs was first introduced in Malaysia arround 1975, and Kedah was the first artificial reef's project was implemented (Latun and Abdullah, 1991; Ali, (2007). In May 1975, artificial reefs have made by used tires in PulauTelur followed some other areas near to PulauPayar. Beside that, artificial reef also made by old boats and fishing vessels by foreigners who intruded country border. However, after 1995, artificial reef from tire were not used because it make the marine environment is damaged (Collins, Jensen, Mallinson, Roenelle and Smith, 2002; Sullivan, 2006)

Starting in 1986, artificial reefs was produced from PVC materials, ceramics, and cement concrete consisting of various forms (Islam, Kusairi, Shaufique, Aswani and Ali, 2013). Size artificial reefs also changed according to the location and seabed conditions. A large-sized artificial reefs in the area of Zone A in order to prevent trawlers from encroaching to the zone and protect resources from trawl net. Artificial reefs will be placed in the area between two to five nautical miles from the coast, in water depths ranging from 15 to 30 meters (DOFM, 2012; Islam et al, 2013) Although the artificial reef structures may cause trawl nets and drift nets damaged, and it is to stop trawlers and purse seines from disobeying the regulations. The trawlers not only cause small fish caught in the nets but this sea habitats are destroyed when a large part of the reef that was stuck in the nets (Ali, Mahyam, Illias, Abdullah, Yaacob and Zakaria, 2008)

According to DOFM, (2012); Islam et al, (2013), the implementation of artificial reefs is intended to:

1. Creating an ecosystem that serves as a sanctuary,

2. Provide a breeding and nursery areas for fish and other marine life,

3. Restoring and protecting marine habitats were destroyed by fishing activities, and

4. Helps restore and enhance fisheries resources in coastal areas to catch fish by traditional fishermen increased.

Studies on the effects of artificial reefs to the tradisional fishermen still limited. Study done by Johnson, Barnett, Martini, Craft, Ambrose and Purcell (1994) and Venkatasami and Mamode, (1995) found that artificial reefs provide a positive economic impact to the fishermen. In addition, there are several studies in Malaysia such as Islam et al (2013), Ali et al (2013) also showed a positive effect of artificial reefs to 
fishermen. The important issues for the policy makers is the effectiveness of artificial reef to increase catches of fishermen. This is because goverment spend around RM20 million starts from introduced of artificial reefs until now.

\section{Literature Review}

In early 1900, a fisherman found fisheries resources more in areas with rocky seabed and have the sinking ship. Accordingly, the traditional fishermen began practicing artificial reefs to increase catches of fish (Hung, 1988; Shahabuddin et al, 2011). Artificial reef designed by the government to improve fisheries resources thereby increasing the income of fishermen through the catch (Ali et al, 2013; Islam ,Kusairi, Fatimah, Aswani and Illisriyani, 2010; Omar, 2013; MohdFakhrudin, 2013 (a); MohdFakhrudin, 2013 (b).

Artificial reefs in Malaysia had been implemented for over 40 years through the provision of MFDA and DOFM with a total more than RM20 million. This is a huge ammount and invested by the goverment to ensure that fishery resources is stable and increased for the future. This program aims to increase the fishery resources and fishermen's income. To look the effectiveness of artificial reefs to fishermen, there are studies conducted in Malaysia such as Islam et al. (2010), Islam et al. (2013), Ali (2007), Hung, (1988), Latun and Abdullah (1991) and Ali et al. (2008). The study was conducted to see the effect of artificial reefs to fishermen in Malaysia and according to Hung (1988) and Islam et al. (2011) study on the effect of artificial reefs is still limited and only focused on income not others factors.

Compared to developed countries and other developing countries, the study of artificial reefs have been implemented for a long time ago. Among Leitao (2013); Watanuki and Gonzales (2006); Polovina and Sakai (1989), artificial reefs as a tool that can help improve fisheries resources, particularly in developing countries. Watanuki and Gonzales (2006) showed that artificial reefs have been able to improve the efficiency of fishing, protect beaches from erosion, encroachment of trawlers and attractions for divers.

Islam et al. (2010) to see the effects the implementation of artificial reefs in Peninsular Malaysia. The results showed that artificial reefs can increase the income of fishermen. Data in Islam et al. (2010) is the catch data based on type, operating costs and monthly revenue from fishing. Islam et al. (2010) used for the descriptive analysis showed that the average quantity of the catch, the fish landing and operating costs.

Islam et al. (2013) also studied the effect of artificial reefs to fishermen with the objective of the study is to look the economic impact of the implementation of artificial reefs in Terengganu and the second objective is to provide information to policy makers to manage the stability of the fishery resources. The results from the model, Islam et al. (2013) found that the income of fishermen in the area of artificial reefs less than the area that do not have artificial reefs. This is in contrast to studies was conducted by Islam et al. (2010) found that artificial reefs give the impact to the fishermen in that area. The difference in the results of this study may be due to several factors that can affect the results. The problems identified from the study are fishermen do not know about the location of artificial reefs, fishing costs are rising, conflicts between fishermen, the inclusion of small trawlers during the monsoon season and an artificial reef structure is not protected.

In addition, Ali et al. (2013) also shows the effectiveness of artificial reefs. The main objective of study in Ali et al. (2013) is to review the socio-economic impact from the implementation of artificial reefs among fishermen using different tools. The study area is Kelantan, Terengganu, Selangor, Johor, Pahang, Penang, Kedah, Perak, Perlis and Negeri Sembilan. Ali et al. (2013) used the interview method, in which a total of 506 fishermen involved. Target groups methods carried out in which the question has been set and is divided into six parts. The first section on demographics, second is knowledge of artificial reefs, third part is the location of fishing, the fourth is knowledge of the latest equipment on artificial reefs, the fifth part of the perception of the fishermen on the management and the last part is 
related to socio-economic impacts of artificial reefs.

Results of the study revealed that as many as $78 \%$ said there was an increase in income, while the rest have no improvement. This is contrast to studies carried out by Islam et al. (2013). The difference results is due to differences in study variables where Islam et al. (2010) took operating costs, but Ali et al. (2013) does not take costs for the operation of fishing as variables. This difference can give the effect fishermen's income. If the cost incurred is equal to or more than the total income, this will cause the fishermen do not benefit from the project, but if this value is ignored losses suffered by fishermen can not be known and it is seen as a positive result by the fishermen.

David and Ismaili (2003) study on artificial reef ball type (reef balls) also showed a positive effect on the growth of fishery resources. The reefs in acting as a new reef habitat that give the benefits to the fishermen and divers. These reefs also act to prevent the invading trawlers from entering the area, and also approaching the turtle breeding area. The study was conducted in BatuPenyu near PulauTalangTalang. The methods use is the Line Transect (LIT). This model is used to estimate the life of a group within a group in a particular area. Through this method, changes in coral on the stone will be recorded. The establishment of this new artificial reefs help marine habitats have new breeding ground, particularly coral species that span the areas of marine habitat get food. While after two years, this type of ball overgrown reef algae and invertebrates as a source of food for some species. This has led to an increase in the number of fish populations in the area (David and Ismaili, 2003).

Seaman and Hoover (2001) in a study looking at the impact of artificial reefs on recreational fishing where it affects fishermen and divers. Through a survey was conducted, fishermen more attract to fishing in the area of artificial reefs and by $13 \%$ diver makes the artificial reefs as location to dive. Fishermen and divers also expressed their willingness to pay will be made to build a new artificial reef to obtain high interest.

In addition, Ditton, Thai, Riechers and Osburn (2002) see the effects on the economy from the artificial reefs. Ditton et al. (2002) also see the effects of artificial reef to divers in that area. The study was conducted in Texas with total of 528 respondents participated in the survey. It is conducted through email and phone calls. Ditton et al. (2002) using the total output, income, and the number of workers involved. Therefore, to see the effects of the economic impact, Ditton et al. (2002) takes into account the total expenditure and the number of trips per day. Number of times divers do diving in that area will be taken to see the number of overall expenses incurred. The more often divers do this activity shows that many divers benefit get from the artificial reefs

The total trip expenses $\mathrm{x}=$ total amount spent

Azhdari, Ibrahim, Arshad, Shohaimi, Ajdari and Ibrahim (2012) in the study also shows the effectiveness of artificial reefs. Based on this study, Azhdari et al. (2012) used four types of artificial reefs like reef balls, LanehMahi,used items and combination of all three types of materials from groups A, B and C. Laneh Mahi is a reef that traditionally use fronds that placed in a sea area with the aim of increasing the number of the region's fisheries. Therefore, to see the effect obtained through these types of reefs every area of artificial reefs will be checked every three months. At each visit, nets used and placed in each study area for 5-7 days. Then haul visits and other types of fish will be classified according to species and groups of fish. Results are calculated in terms of the amount of weight $(\mathrm{kg})$.

\section{Research Method}

A total of 240 fishermen from Kuala Kedah and Pulau Langkawi, Kedah involved in this research. In addition to fishermen, the staff from Department of Fisheries Malaysia (DOFM) and the Fisheries Development Authority of Malaysia (FDAM) are also involved. The interviews was conducted to see the effect of artificial reef that received by fishermen. Before carrying out the questionnaire, questions will be appropriately designed in advance and it should be reviewed prior to submission to the 
fishermen. A pilot study was conducted in Pulau Tuba, Langkawi, Kedah on October 5, 2014 and the second on October 31, 2014. The first pilot study the reliability (Cronbach's alpha) is $44 \%$ and the second is $78 \%$. From this value indicates the reliability is high and the questions this study is suitable for use in this study.

After a pilot study carried out, the latest questionnaire formed and divided into 5 main sections as well as a number of questions in each fraction major sections: Section of this questionnaire focuses on the Head of Household $(\mathrm{HoH})$. It will include questions related to the role of $\mathrm{HoH}$ and also about the background of the respondent. Where it will involve some fractions such as questions relating to the fishing experience, knowledge of fisheries, fishing equipment and appropriate fishing techniques, the tendency to choose the type of fishing equipment, and the season. In addition, questions must be asked regarding respondent demographics such as gender, race, marital status and so on to get information about the fisherman.

The second part includes questions related income and expenses $\mathrm{HoH}$. Where it will be divided into two parts, revenue and expenses. On the revenue side, all of $\mathrm{HoH}$ inflow of money will be calculated. This includes contributions from various quarters and ancillary works. On the expenditure side, the outflow of money all of $\mathrm{HoH}$ will be calculated. The third part, information of assets held by households. Information of facilities and equipment will be assessed household respondents in this section. Through facilities and home furnishings, the living standards of fishermen can be seen.

The fourth part of the fishermen's social relationship. The relationship between the family, the community, and participation in politics will included in social part. This section will also look at the contributions by the fishermen in improving the quality of life. The last part is focused on the role of artificial reefs in the study area. Among the questions that must be asked is the knowledge of fishermen about the role of artificial reefs, the area was carried out and the cost of implementation.

Based on the objectives, the model established,

$\mathrm{Y}=\alpha+\operatorname{cost} 1+\mathrm{No} . \mathrm{F} 2+\mathrm{YxF} 3+\mathrm{Age} 4+\mathrm{No} . \mathrm{Fg} 5+\mathrm{No} . \mathrm{H} 6+\mathrm{AR} 7+$ Equip8+ Sea $9+e ́$ which,

Cost = Cost of fishermen's daily operations such as fuel, food and other necessities like a bait.

No.F $=$ Frequency fishermen out fishing day preformanceNo.Fg = number of fishermen involved in a boat

No.H $=$ Number of households of fishermen Age = age of fishermen

equip $=$ Fishing equipment

$\mathrm{YxF}=$ Income from others activities sea $=$ Season

$\mathrm{AR}=$ Artificial reefreefs

This model is analyzed using logit model which, artificial reefs is a dummy variable with $0=$ no artificial reef areas, $1=$ area has an artificial reef.

\section{Finding}

\section{1 characteristics of fishermen}

Age

From the research was conducted that showed involvement of young fishermen is more than the older. This isbecause the factors such as inherited the job from family member. Beside the encourage from family members, natural factors also give the reason for these people to choose work as a fisherman. It is supported by Stephen and Barry (1995), the choice of employment population is based on the region's economy. For example, residents of the island and close to sea will choose jobs related fisheries sector, while the population of the rural areas tendency to choose jobs based on agriculture is high.

In addition, from the results of interviews conducted, some fishermen are shifted to the industrial sector but do not have the compatibility and back the fisheries sector. The third group is the highest fishermen aged between 40 - 49 years with the number of respondents is $24 \%$, followed by fishermen aged 50 to 
59 years with the percentage of respondents involved is $12 \%$.

\section{An experience}

Fishermen aged over 30 years tend to have experience of more than 7 years and more. This is because based on the study, the fishermen got involved as early as the 20 years and this encouraged fishermen have a lot of experience. After completed the education up to high school level and choose not to further the studies this is an option field to work for residents in areas near the coast (Stephen and Barry, 1995). Fishermen's experience depends on how early fishermen get into this field and also depends on the level of education. For fishermen aged 50 and over, formal education received by them only at the level of primary education. This an encourages fishermen been in this field as early the 13 years and majority have experience more than 36 years.

\section{2 fishing equipments}

Fishing equipment is a requirement for fishermen to proceed the activity. Fishing equipments also will show the characteristics of the fisherman. For example, the class B fishermen called upon the type of nets used like fishing trawlers. Traditional fishermen tend to have simple equipment such as drift nets and canoes or boats compare to comercial fishermen that have more modern equipment. For example, traditional fishermen have a box with ice to store the fish so that it remains fresh compare to comercial fishermen that have a room freezer in boat to put the fish.

\section{Boat and fishing net}

Traditional fishing boat is less than 5 tons. Some fishermen use canoes to collect clams and crabs. The table shows the price of boats purchased by fishermen. Of the total, as many as 150 fishermen said the boat used to catch fish bought at the price of RM10'001-RM15'000. This price includes two types of model boats of wooden and fiberglass model. For a new model like fiberglass boats normally have a high price in market compare to the wooden model. According to the fishermen, wooden model more cheaper than fiberglass because a few factors. This type of boat is the kind of old and owned by fishermen aged 50 years and older. Furthermore, there are also fishermen who buy from other fishermen and get a cheap price. The large-sized boats normally it can accommodate 5 employees of the skipper and crew and costly around RM15'000-RM20'000. Compared to the boat with invesment below RM 10,000 , the number of fishermen involved was small, only around 3 people

For other equipment such as engines, most of the traditional fishermen using outboard engines. This is because the use of outboard engines suitable for the open fiberglass boat. While the engine is also better suited to boats which have an enclosed space such as a trawler. The horsepower (hp) engine for traditional fishing boats are small. This is consistent with the weight of the boat and the boat's small size.

\subsection{Operating costs}

The operating costs is an important thing for fishermen to start fishing operations. These costs are divided into two, fixed costs and variable costs. Fixed costs are the costs of buying a boat, nets, engines and anothers fishing equipment such as fishing lines. While vriable costs include costs such as the cost of fuel, charges for food and bait for fishing.

While for the variable costs, it is calculated based on the total number of days fishermen go to fishing. According to the study, most of the fishermen catch every day except Friday. There are also fishermen out fishing subsidies granted according to the number of 22 days. Fuel consumption by the fishermen is based on the location of the fishermen want to catch fish. Normally not more than 5 nautical miles. The minimum usage is in approximately around 10 liters that costly RM20. If the fishermen want to find a different location usually the fuel quantity will be add to make sure oil sufficient for a every trip. 
In addition, the cost of the food supply is also required and the fishermen just allocate a smaller amount arround RM10. There are also fishermen who bring food from home to save the costs. While the cost for bait is depends on the type. For raw bait it's cheaper than artificial bait. For example, artificial bait for fishing can be reached RM50but it can be used repeatedly compare to raw fish like macarel just arround $R M 5 / \mathrm{kg}$.

\subsection{Effect of artificial reefs}

The benefits of artificial reefs asked to fishermen in five levels or stage that can directly choose by fishermen. The first stage is very advantageous, second are not beneficial, the third is not sure. The first stage and the second will show the fishermen said that artificial reefs not give any benefits that could help improve catches of fish and income. The third stage, the fishermen feel unsure whether artificial reefs benefit or not to fishermen. While the fourth and fifth level shows fisherman said artificial reefs give the benefit and very beneficial. Number 1 until 5 that can show the exactly how the fishermen think about effect of artificial reef.

The majority of fishermen agree that articial reef give the impact to income. Between the benefits specified by the fishing is increasing the number of catches in the artificial reef area. These factors encourage some fishermen to make the location of artificial reef as a main location for fishing. This location will help fishermen save fuel consumption because the fishermen already know where to put the nets in order to get more catch of fish and to avoid damege to the net.

In this location, there are also various species of fish compared to other areas. The species is classified as grade A fish where it has a high price in the market. Besides that, the other benefits such as area artificial reefs can prevent the invasion of trawlers and areas suitable to take the tourists to fishing in that area. In addition, when fishermen take the tourist to that area to fishing, this also will help to increase income through the tourist.

\subsection{Income of the fishermen}

The results showed that the artificial reefs was significant to give the effect on income of fishermen. To see the level of fishermen's income, it is divided into two, that is 0 to income of less than RM1,000, while 1 to income more than RM1,000. This is to see the difference in fishermen's income with previous studies. According to the BanciSendi (2007) the number of fishermen who earn RM1000 is still at low rate.

According to a study conducted shows majority of fishermen have income of more than RM1,000. A total of 165 fishermen have income more than RM1000 compare to the 75 of fishermen have incomes less than RM1000. This clearly shows the changes in the income of fishermen.Furthermore, there are other factors that encourage fishermen to increase income from artificial reef. Which is include bringing the tourists to fishing in the area. This can help fishermen raise the income through artificial reefs.

\section{Conclusion}

From the results of the study clearly shows that artificial reefs affects the income of fishermen. Artificial reefs not only increase the income, but the area is also used as a travel area for divers. Fishermen also get additional income through the tourists from bring them to the location of artificial reefs for fishing. For fishing enthusiasts, this is an ideal location to attract and give the best results to the fishing. This also increase the income of fishermen, although not through the catches but by bring the tourist go to the area.

Artificial reef studies should be conducted more to make sure artificial reef give the effect to the fishermen. In addition, management should maintain and manage the area of artificial reef in order to prevent the intrusions by the trawler. This is because, it will cause artificial reefs will be damaged if the trawler enter in that area. The damaged will make destroyed breeding grounds and in long term it will effect fisheries resources. 
Maintain and management very important to make sure artificial reef can be solution for fisheries resources. This is because if the artificial reef is not maintained properly, it will cause the loss for various parties. The fishermen who will remain the level of income in the long run but had to switch the direction and looking for another job due the lack of fishery resources. The country will have many problems such as lack of food supplies, unemployment and poverty among the fishermen.

\section{Reference}

Ali, $\quad$ A. 2007. Penyelidikantukuntiruandasarlembut $\quad$ di $\quad$ Kedah. Departmenpenyelidikandanpengurusansumberperikanan Marin. Malaysia.

Ali, A., Hussain,M. L, Hamid, S. A. \& Abdullah, W. S. W. 2013. Artificial reefs (ARs) program in Peninsular Malaysia a social Assessment on its effectiveness.

Institute of Oceanography and Environment.

Ali, A., Mahyam, M.I., llias, Z.., Abdullah, M. P., Yaacob, K.K.K., \&Zakaria, N. A.

2008. Status tukuntiruan di perairan Terengganu berdasarkanpenilaianimejmenggunakan sonar pengimbassisi. JabatanPerikanan Malaysia. pp57.

Ariff, M.R, Sharir, M. M., Ali, I., Majid. M, \&Hussin, H. 2011. Perkembangan

perusahaanperikanan di semenanjungmalaysia: isudanpersoalan. Jati, Volume 16, 265-299

Ariff, M.R, Sharir, M. M \&Zarina, A. 2007. Masalahnelayantradisional di Semenanjung Malaysia: Penyelesaiantanpakesudahan. Jati, Vol. 12.

Azhdari H., Ibrahim, M. Arshad, A., Shohaimi, S.,Ajdari Z., \& Ibrahim, Z.Z. 2012.

The effect of artificial reefs on fish assemblage versus natural sites in the Bandar Lengeh-Iran.Iranian Journal of Fisheries Sciences 11.1. pp 1-12.

BanciSendi. 2007. Sosioekonominelayandan data isirumah. LembagaKemajuanIkan Malaysia. Malaysia.

Collins, K. J., Jensen, A. C., Mallinson, J. J., Roenelle, V. \&. Smith, I. P.. 2006. Environmental impact assessment of a scrap tyre artificial reef. Journal of Marine Science Volume 59, Pp. S243-S249.

Daud. A. \& Ismaili. B. Pit. 2003. Study on reef ball at BatuPenyu nearby TalangTalang Island. Malaysia.

Ditton, R. B, Thailing C. E, Riechersz. R., \&Osburn, H. R. 2002. The Economic Impacts of Sport Divers Using Artificial reefs in Texas Offshore waters. Gulf and Caribbean Fisheries Institute. p344-356.

DOFM. 2001-2014. Department of Fisheries Malaysia. www.dof.gov.my Malaysia.

DOS. 2001-2014. Department of Statistics Malaysia. www.dos.gov.my.Malaysia.

Fakhrudin, M. Y. (a). 2013. Tukundibina, pendapatandijana. BeritaPerikanan:. 84:5. JabatanPerikanan Malaysia. Malaysia. 
Fakhrudin, M. Y. (b). 2013. Tukuntiruanterbuktiberiimpakpositifkepadanelayantradisional Terengganu BeritaPerikanan: 84:6. JabatanPerikanan Malaysia.

Hung. E. W. F, 1988. Artificial reef development and management in Malaysia. Fisheries Reseacrh Institute, Department of Fisheries, Ministry of Agriculture, Malaysia.

Islam, G.M.N., Kusairi M. N., Fatimah M. A., Aswani F. M.N. \&Illisriyani, I. 2010.

assessing the impact of artificial reefs in Malaysia. Institute of Agricultural and food policy studies.

Islam, G.M.N., Kusairi M. N, Shaufique, F. S., Aswani F. M.N \& Ali, A. 2013. Socio economic impacts of artificial reefs on artisanal fishers in Peninsular Malaysia.

Institute of Agricultural and food policy studies.

Johnson, T.D., Barnett, A.M., De Martini, E.E., Craft, L.L., Ambrose, R.F., \&. Purcell, L.J. 1994. Fish production and habitat utilization on a southern California artificial reef. Bull. Mar. Sci. 55. 2-31, 709-723.

Latun, A. R. \& Abdullah, M. P. 1991. Artificial reef in Malaysia: A country review paper. Fisheries Reseacrh Institute, Department of Fisheries, Ministry of Agriculture,Malaysia.

Leitão, F. 2013. Artificial reefs: from cological processes to fishing enhancement tools. Brazilian journal of oceanography, 61.1:77-81,

Maznah. O. 2013. Penerajuindustrilautdalambuktikankemampuan. BeritaPerikanan.JabatanPerikanan Malaysia.

MFDA. 2001-2014. Malaysian Fisheries Development Authority. http://www.lkim.gov.my. Malaysia.

Omar Saad. 2013. Perikananrekreasijanjikanpulanganlumayan. BeritaPerikanan: 84:9. JabatanPerikanan Malaysia.

Polovina, J.J.,\&. Sakai, I., (1989). Impacting of artificial reefs on fishery production in Shimamaki. Japan. Bulletin of Marine Science. 44.2.997-1003.

Saad, O. 2013. Lesen sampan khasditarikbalikjikagunapukatsorong. BeritaPerikanan: 84:5. JabatanPerikanan Malaysia

Shahbudin, S., Hafifi Hafiz, Z., Akbar, J.B., Kamaruzzaman, B.Y. \&. Jalal K.C.A., 2011. Distribution and Diversity of Corals on Artificial Reefs at PasirAkar and Teluk Kalong, Redang Island, Malaysia. Journal of Applied Sciences, 11: 379-383.

Seaman, W. J. 2002. Unifying trends and opportunities in global artificial reef research, including evaluation. Journal of Marine Science, 59: S14-S16.

Seaman, W. J., \& Hoover, A. 2001. Artificial reefs: The Florida Sea grant connection. Florida Sea grant.

Stephen, B. \&. Barry D.C. 1995. Small island states and sustainable development: strategic issues and experience. Environmental Planning Issues. No. 8, 
September 1995.

Sullivan, J.P. 2006. An assessment of environmental toxicity and potential contamination from artificial turf using shredded or crumb rubber. Turfgrass Producers International.

Tey, J. Y. S., Shamsudin, M. N., Mohamed, Z., Abdullah, A. M., \&. Radam, A. 2008. Emerging food demand behaviors in Malaysia: Incorporating quality effects in demand analyses. MPRA Paper 14832, University Library of Munich, Germany.

Venkatasami, A. danMamode, S. A. (1995). fish-aggregating devices (fads) as a tool

to enhance production of artisanal fishermen: problems and perspectives. Albion Fisheries Research Center.

Watanuki, $\mathrm{N}$ dan Gonzales, B.J. 2006. The potential of artificial reefs as fisheries

management tools in developing countries. Bulletin of Marine Science, Volume 78, Number 1, pp. 919.11 . 
